
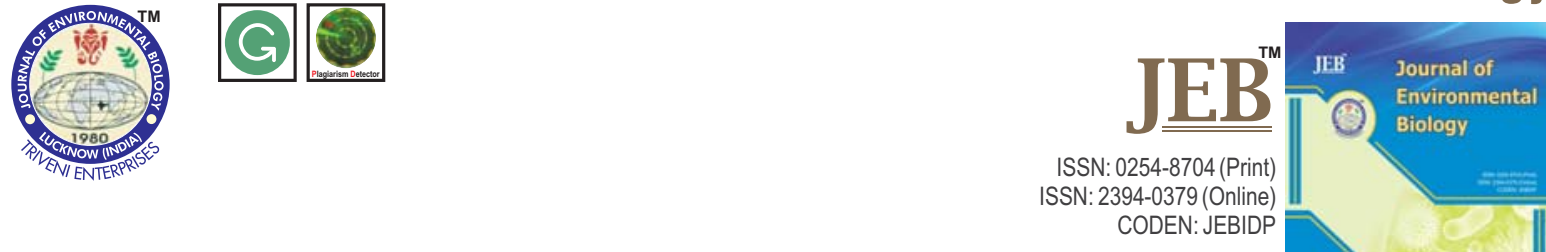

\title{
Evaluation of transgenic peanut plants encoding coat protein and nucleocapsid protein genes for resistance to tobacco streak virus and peanut bud necrosis virus
}

Authors Info

A.S. Patil ${ }^{1,2}$, R. Thankappan ${ }^{1 *}$, R. Mehta', R. Yadav', A. Kumar', G.P. Mishra', J.R. Dobaria', P.P. Thirumalaisamy ${ }^{1}$ and R. K. Jain ${ }^{3}$ ${ }^{1}$ Crop Improvement Unit, ICAR-Directorate of Groundnut Research, Junagadh-362 001, India

${ }^{2}$ Department of Genetics and Plant Breeding, College of Agriculture, Junagadh Agricultural University, Junagadh-362 001, India

${ }^{3}$ Division of Plant Pathology, Advanced Centre for Plant Virology, ICAR-Indian Agricultural Research Institute, New Delhi-110 012, India

*Corresponding Author Email : radhakrishnan.nrcg@gmail.com

Key words

Allotetraploid,

Biotic-stress resistance,

necrosis virus,

Tobacco streak,

Transgenic plants virus

Publication Info

Paper received : 21.10 .2015

Revised received: 12.04 .2016

Re-revised received : 16.07 .2016

Accepted: 12.09 .2016
Abstract

Aim: Genetic engineering of peanuts (Arachis hypogaea L.) via genes encoding for coat protein (CP gene) of Tobacco streak virus (TSV) and nucleocapsid protein (NC gene) of a Peanut bud necrosis virus (PBNV) were used to impart concurrent resistance against the stem and bud necrosis diseases. The main objective of this study was to determine whether the CP/NC-mediated resistance strategy could be applied for developing the transgenic peanut plants, by utilizing CP gene of TSV and NC gene of PNBV.

Methodology: The transgenic lines of peanut cv. K-6 were characterised for integration, inheritance and expression of transgenes through PCR, RT-PCR and quantitative PCR (qPCR) analysis. The transgenic plants were artificially challenged with viruses under confined glasshouse conditions and the load of virus particles were confirmed using DAC-ELISA, RT-PCR and histopathology in both transgenic and wild-type (WT) plants.

Results: The marker-free transgenic groundnut plants carrying TSV-CP+PBNV-NC genes witnessed delayed and less intense symptoms after viral inoculation, suggesting underlying resistance via a coat protein/nucleocapsid-mediated mechanism and indicated partial/non-durable resistance to TSV and PBNV.

Interpretation: The marker free Agrobacterium-mediated transformation technique can be successfully used to generate transgenic peanuts having resistance to both llarvirus and Tospoviruses. This strategy may be applied to commercially important crops that are affected by llarvirus and Tospoviruses.

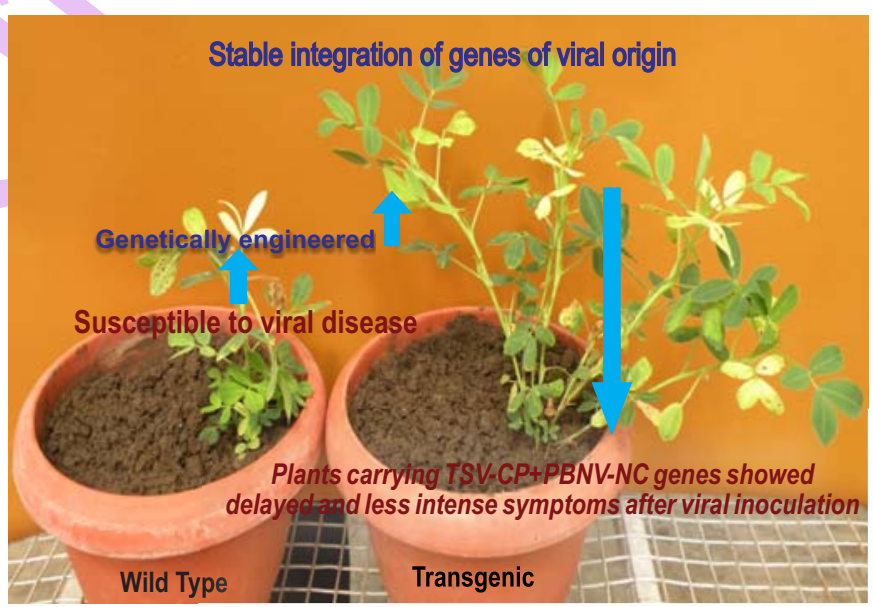




\section{Introduction}

Peanut (Arachis hypogaea L.) is a self-pollinated, allotetraploid legume of family Fabaceae, which can play a major role in bridging the edible oil gap in India. The current Indian peanut productivity of $1804 \mathrm{~kg}^{-1}{ }^{-1}$ is deplorably low as compared to $3614 \mathrm{~kg} \mathrm{ha}^{-1}$ in China and $4496 \mathrm{~kg} \mathrm{ha}^{-1}$ in USA(FAOSTAT, 2014). About $80 \%$ of the peanut area in India is monsoon dependent and main reasons for low yield is not only the rainfed nature of the crop but also various biotic-stresses including viral diseases like peanut stem necrosis disease and peanut bud necrosis disease caused by Tobacco Streak Virus (TSV) and Peanut Bud Necrosis Virus (PBNV), respectively (Reddy et al., 2002; Mishra et al., 2015; Kandakoor et al., 2014, Singh et al., 2015a;b).Moreover, viral diseases are known to restrain the production in all peanutgrowing areas of the world (Mehta et al., 2013).

TSV is distributed worldwide as it has been reported from North and South America, Europe, South Africa, India, Australia, New Zealand, Netherlands, Pakistan and Iran (Jain et al., 2008). In India, during the year Kharif 2000, TSV was epidemic in Anantapur district of Andhra Pradesh and caused inflicting loss to the tune of 47.0 million USD (Reddy et al., 2002; Prasad Rao et al., 2003). In peanut, TSV necrotic lesions appear first on young leaves and later spread to the petiole and stem, killing the top growing buds while, spots may appear on pegs and pods also (Reddy et al., 2002).

Furthermore, PBNV which is vectored by thrips is restricted to South and Southeast Asian countries, including India, Nepal, Sri-Lanka, Myanmar, Thailand and parts of China. In India, PBND alone has been estimated to cause annual loss of 89 million USD (Reddy et al., 1995). Initial symptoms of PBNV appear on young quadrifoliate leaves as mild chlorotic spots and later develop in to necrotic and chlorotic rings. In rainy and post rainy seasons, necrosis of terminal bud is the main characteristic symptom.

Strategies for management of viral diseases normally include control of vector population using insecticides, resistant cultivars and several cultural practices can reduce the incidence of TSV and PBNV. But, the above components of integrated diseases management so far did not prove competently favourable. Moreover, for both, TSV and PBNV the genetic resistance against virus has not been reported in the gene pool of cultivated peanut, hence no cultivar, resistant to these diseases could be developed till date. Under these circumstances, direct gene transfer using genetic transformation method remains the only choice to have peanut plants with genetic resistance to TSV and PBNV.

Coat protein mediated resistance is well-known as an effective means of protection against viral infection and avoidance of crop loss (Baulcombe, 1996; Beachy, 1997). CP genes has been reported to grant partial or complete resistance against TSV in tobacco (Pradeep et al., 2012) and potato virus $Y$ in potato plants (Hefferon et al., 1997).

Transgenic peanut progenies expressing nucleocapsid protein of TSWV, when subjected to natural virus infection under field conditions showed resistance to TSWV (Yang et al., 2004). In addition, transgenic plants harbouring sense and translationally defective or antisense NC protein gene have also been developed and tested for expression in progenies (Li et al., 1997 and Yang et al., 1998). Additionally, the transgenic progenies of peanut cultivar, MARC-1 expressing antisense NC gene, showed significantly lower occurrence of spotted wilt over wild-type (WT) plants, without fail over a 3-year period (Yang et al., 2004). In another report, transgenic peanut plants developed from coat protein gene for Tobacco streak virus showed resistance with traces or refusal systemic growth of virus up to T3 generation (Mehta et al., 2013).

Therefore, considering the economic importance of TSV and PBNV in peanut cultivation, we have resorted to the marker free Agrobacterium-mediated genetic transformation approach using $C P$ and $N C$ genes to develop virus resistant genotypes in peanut. The main objective of this study was to determine whether the CP/NC-mediated resistance strategy could be applied for developing the transgenic peanut plants, by utilizing the CPgene of the TSV and NC gene of PNBV.

\section{Materials and Methods}

Gene construct and plant materials : The 717 bp CP gene (GenBank Acc. No. AF400664.1) of TSV and 831 bp NC gene (GenBank Acc. No. FJ749261.1) of PBNV were introduced into the binary vector PCAMBIA 1305.1 by replacing HygR and GUS PLUS $^{T M}$, genes. The $2 X$ CaMV $35 S$ and CaMV $35 S$ constitutive promoters from the cauliflower mosaic virus were used for constitutive expression controlling of TSV-CP and PBNV-NC genes, respectively. The dual construct transgenic peanut lines of Arachis hypogaea cv. Kadiri-6 (K-6), was transformed and available events were used as experimental material. The dual gene (TSV-CP and PBNV-NC) construct was obtained from Advanced Centre for Plant Virology, IARI, New Delhi, India.

\section{Molecular analysis}

PCR analysis : The PCR screening of putative transgenic plants were done to confirm the presence of transgenes. Genomic DNA was extracted from fresh terminal leaves (Cuc et al., 2008) and PCR was performed using gene specific primer pairs for TSV-CP and PBNV-NC genes (Table 1). The amplification of $717 \mathrm{bp}$ for TSV-CP and $654 \mathrm{bp}$ for PBNV-NC genes were obtained. For TSV$C P$ gene, $P C R$ reaction was set in $25 \mu$ l volume containing $5 \mu$ of $5 x$ PCR buffer, $2 \mu \mathrm{l} 25 \mathrm{mM} \mathrm{MgCl}_{2}, 2 \mu \mathrm{l}$ of $2 \mathrm{mM}$ dNTP mix, $25 \mathrm{pmol}$ of each primers, $0.25 \mu \mathrm{l}$ of $1 \mathrm{U}$ Taq DNA polymerase and $100 \mathrm{ng}$ of 
subtracting $18 \mathrm{~S}$ rRNA $\mathrm{C}_{T}$ from TSV-CP and PBNV-NC $\mathrm{C}_{T}$ in a given sample. The $\Delta \Delta C_{T}$ values were determined by subtracting the $\Delta \mathrm{C}_{\mathrm{T}}$ of calibrator from $\Delta \mathrm{C}_{\mathrm{T}}$ of different. The outcomes were evaluated statistically by relative fold expression of TSV-CP and $P B N V-N C$ transcripts. The primers for TSV-CP, PBNV-NC and 18S rRNA genes used for quantitative PCR expression analysis were designed using Primer Express ${ }^{\circledR}$ version 3.0 from Applied Biosystems and synthesized from IDT Inc., USA.

Virus resistance assays : Transgenic plants and WT were grown in confined glasshouse for 2 wk(s)before virus inoculation. Plants were mock-inoculated with phosphate buffer or inoculated with leaves sap extracts [diluted in $0.1 \mathrm{M}$ phosphate buffer $(\mathrm{pH}$ 7.2)] from cowpea plants infected with TSV and PBNV. Leaves from infected cowpea plants with outstanding symptoms were selected for inoculums. The leaves were macerated using mortar and pestle in chilled inoculation buffer (for $100 \mathrm{mg}$ leaves $0.1 \mathrm{M}$ phosphate buffer, ( $\mathrm{pH} 7.0$ ) in 1:10 w/v ratio). Leaves of transgenic plants were dusted with carborundum (320 grit) powder and then inoculums of TSV and PBNV were applied using a cotton swab(Mehta et al., 2013).Thereafter, leaves were washed with distilled water and the inoculated plants were observed for viral symptoms.

Direct antigen coated enzyme linked immuno sorbent assay (DAC-ELISA): DAC-ELISA was performed for the detection of TSV and PBNV with $500 \mathrm{mg}$ leaf samples of infected transgenic, WT and un-inoculated healthy plants (Hobbs et al., 1987). 96-well polystyrene micro titer plates were coated with leaf extracts prepared in $50 \mathrm{mM}$ sodium carbonate buffer, (pH 9.6). The Polyclonal antiserum (obtained from ICRISAT, Hyderabad) was raised against $C P$ of TSV and $N C$ of PBNV and used in dilutions of 1:10,000. Goat anti-rabbit immunoglobulin conjugated to alkaline phosphatase (Sigma-Aldrich, St. Louis) were used at 1:2,000 dilution of commercial stock. P-nitrophenyl phosphate at $0.5 \mathrm{mg}$ $\mathrm{ml}^{-1}$ was used as substrate. Absorbance was recorded at $405 \mathrm{~nm}$ after incubation for $1 \mathrm{hr}$ at room temperature following the totalling of the substrate using a BioTek Make ELISA Plate Reader (Model Epoch). The samples showing at least three times more value than their respective healthy controls were considered positive.

RT-PCR base detection of challenge inoculum load of TSV and PBNV : After challenge inoculum of TSV and PBNV to transgenic and WT peanut, RT-PCR analysis was performed to determine the existence of virus inoculums load. Total RNA from the leaves of transgenic and WT was extracted, using RNeasy plant mini kit (Qiagen, $\mathrm{GmbH}$ ). Following first strand cDNA synthesis (Thermo Scientific, USA), the RT-PCR was performed with TSV (Putative viral replicase; GenBank Acc. No.: NC_003844.1) and PBNV (Nonstructural movement protein; GenBank Acc. No.: HQ259244.1) gene specific primers (Table 1) designed using Primer Express ${ }^{\circledR}$ software version 3.0 from Applied Biosystems and synthesised from IDT Inc., USA. The primer pairs gave amplification of 507 bp for TSV-putative viral replicase gene and 406 bpf or PBNV-non-structural movement protein gene. For TSV- putative viral replicase gene, RT-PCR reaction was set in $25 \mu$ reaction volume containing $2.5 \mu$ l of $5 x$ PCR buffer, $2 \mu \mathrm{l} 25 \mathrm{mM} \mathrm{MgCl}_{2}, 1.6 \mu$ l of $2 \mathrm{mM}$ dNTP mix, $25 \mathrm{pmol}$ of each primers, $0.20 \mu \mathrm{l}$ of $1 \mathrm{U} \mathrm{Taq}$ polymerase and $100 \mathrm{ng}$ of cDNA as template. Thermo-cycler conditions were set as initial de-naturation: $94^{\circ} \mathrm{C}$ for $5 \mathrm{~min}$; then 35 cycles of $94^{\circ} \mathrm{C}-30 \mathrm{sec}$, $58^{\circ} \mathrm{C}-30 \mathrm{sec}, 72^{\circ} \mathrm{C}-1 \mathrm{~min}$ and final extension at $72^{\circ} \mathrm{C}$ for $7 \mathrm{~min}$ and for PBNV-non-structural movement protein gene RT-PCR reaction was set in $25 \mu$ reaction volume containing $5 \mu$ l of $5 x$ PCR buffer, $2 \mu \mathrm{l}$ of $25 \mathrm{mM} \mathrm{MgCl}_{2}, 2.5 \mu$ of $2 \mathrm{mM}$ dNTP mix, 25 pmol of each primers, $0.25 \mu \mathrm{l}$ of $1 \mathrm{U}$ Taq polymerase and $100 \mathrm{ng}$ of cDNA as template. Thermo-cycler condition was set as initial denaturation: $94^{\circ} \mathrm{C}$ for $5 \mathrm{~min}$; then 35 cycles of $94^{\circ} \mathrm{C}-15 \mathrm{sec}, 52^{\circ} \mathrm{C}-15$ $\mathrm{sec}, 72^{\circ} \mathrm{C}-1.30 \mathrm{~min}$ and final extension at $72^{\circ} \mathrm{C}$ for $7 \mathrm{~min}$. The PCR products were analysed on $1.2 \%(\mathrm{w} / \mathrm{v})$ agarose stained with ethidium bromide, scanned and documented using a Fuji FLA5200 imaging system. The plants whose sample gave amplification with respective primer pairs were confirmed for presence of virus. A control devoid of template cDNA was also used as reaction control.

Histopathology of wild type and transgenic leaves for micronecrosis symptoms of TSV and PBNV: To visualize plant cell death (micro-necrosis), leaves of TSV and PBNV infected transgenic and wild type peanut plants were stained with lactophenol-trypan blue (Takemoto et al., 2003). First, infected leaves were boiled for $2 \mathrm{~min}(\mathrm{~s})$ in lacto-phenol-tryphan blue stain (10 $\mathrm{ml}$ of $\mathrm{H}_{2} \mathrm{O}, 10 \mathrm{ml}$ of lactic acid, $10 \mathrm{ml}$ of glycerol, $10 \mathrm{~g}$ of phenol and 10 $\mathrm{mg}$ of trypan blue). Afterwards, the leaves were allowed to cool at room temperature for $1 \mathrm{hr}$ and the stain was replaced with distaining solution $(75 \mathrm{ml}$ of glycerol, $75 \mathrm{ml}$ of acetic acid and 225 $\mathrm{ml}$ ethanol). Blue colour stained leaves were monitored and photographed.

\section{Results and Discussion}

In PCR, gene-specific primer pairs, RKJ-1 and RK-4 gave full-length amplification for TSV-CP (717 bp) and partial amplification for PBNV-NC genes (654 bp), respectively, in transgenic lines and positive control (pCAMBIA1305.1 TSVCP+PBNV-NC plasmid) (Fig. 1).No amplification was observed in non-transgenic peanut (cv. K-6) lines. Mehta et al. (2013) also reported $\sim 750 \mathrm{bp}$ amplified fragment of TSV-CP through genespecific primers in $P C R$ analysis of single gene transgenic peanut lines, respectively.

A total of 354 plants (T3) from five events (E1-E5) were PCR screened with PBNV-NC gene specific primer from which 192 plants were found PCR positive. Those above T3 five events (E1-E5) plants were used for further characterization. In T3 progeny highest numbers of $P C R$ positive transgenic plants were observed for eventE3. 

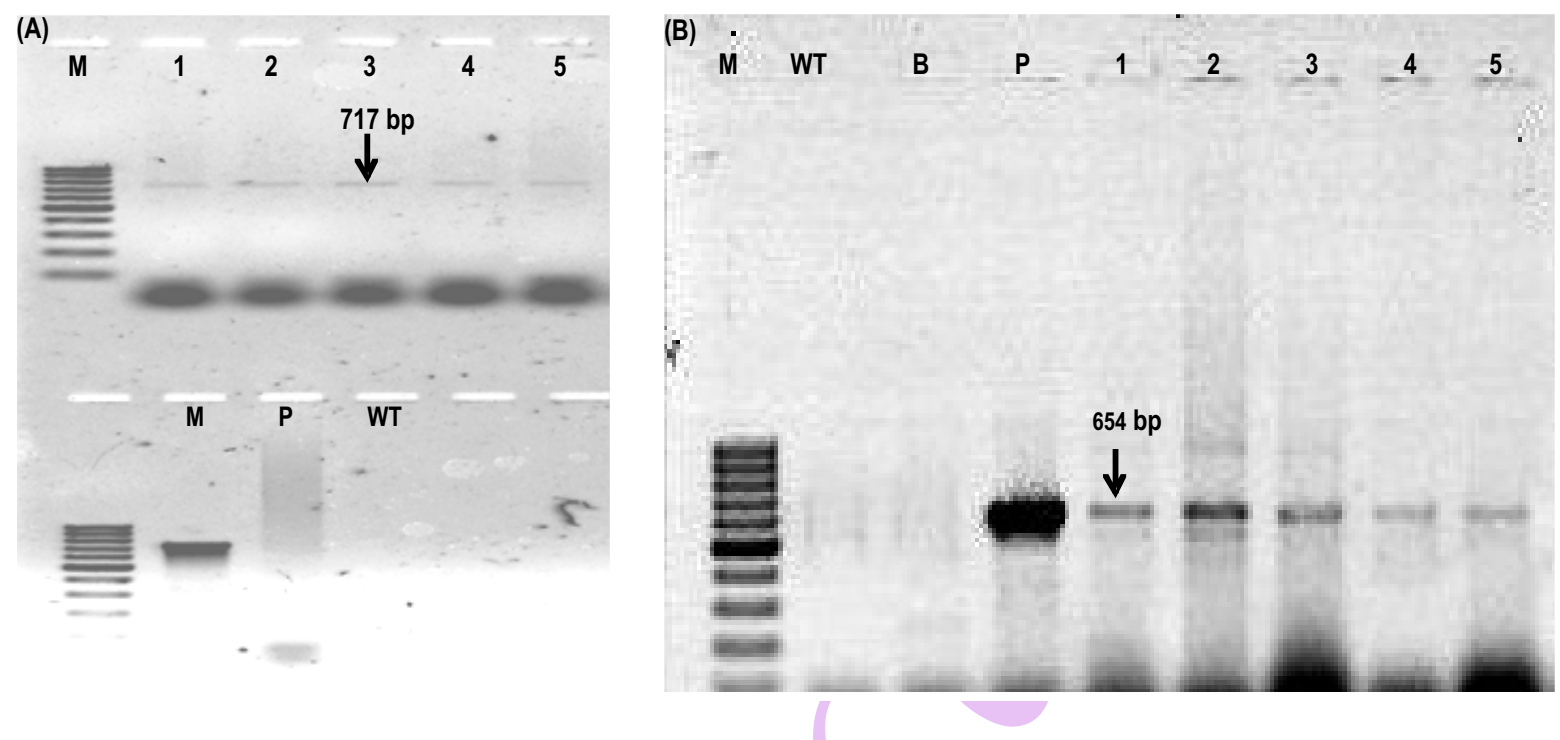

Fig. 1: PCR analysis. (A) PCR screening of TSV-CP gene in transgenic peanut plants. TSV-CP gene-specific primers (RKJ-1) were used for PCR amplification and the size of expected product was $717 \mathrm{bp}$ as that of the full-length TSV-CP coding sequences (cds). (B) PCR screening of PBNV-NC gene in transgenic peanut plants. PBNV-NC gene-specific primers (RK4) were used for PCR amplification and the size of expected product was 654 bp as that of the partial-length PBNV-NC cds. Lanes, M: 100 bp ladder, WT: wild type plant (cv.K-6), B: blank, P: positive control (pCAMBIA1305.1 TSV$C P+P B N V-N C$ plasmid), WT: wild type peanut plant (cv.K-6) and 1-5: transgenic peanut lines represented by their identity number (E1 to E5)

Table 2: Segregation analysis transgenic peanut lines in T1 generation

\begin{tabular}{lllllllll}
\hline Events & $\begin{array}{l}\text { Total no. } \\
\text { plants }\end{array}$ & $\begin{array}{l}\text { No. PCR } \\
\text { positive plants }\end{array}$ & $\begin{array}{l}\text { No.PCR } \\
\text { negative plants }\end{array}$ & $\begin{array}{l}\text { Expected } \\
\text { ratio }\end{array}$ & $\begin{array}{l}\text { Observed } \\
\text { ratio }\end{array}$ & $\mathbf{X}^{2}$ & $P$ \\
\hline E1 & 10 & 7 & 3 & $3: 1$ & $2.33: 1^{*}$ & 0.13 & 0.40 \\
E3 & 13 & 10 & 3 & $3: 1$ & $3.33: 1^{*}$ & 0.03 & 0.35 \\
E4 & 6 & 5 & 1 & $3: 1$ & $5.00: 1^{*}$ & 0.22 & 0.42 \\
E5 & 7 & 2 & 5 & $3: 1$ & $0.40: 1$ & 8.05 & 0.95 \\
\hline
\end{tabular}

$d f=1 ;{ }^{*}$ Observed ratio is not significantly different from expected ratio at $p=0.05$

The $x^{2}$ analysis was carried out to check goodness of fit. On the basis of expected and observed frequencies of gene specific amplicons, $X^{2}$ test was found non-significant $(p=0.05)$, indicating close agreement between the observed and expected frequencies (Table 2). The $\mathrm{T} 1$ progeny segregation ratio of 3:1was confirmed in three events (E1, E3 and E4); whereas other one event (E5) yielded non-segregating progenies. However, in the event $E 2$, no line was found having minimum sample size of five plants, so they were not included $X^{2}$ analysis. Transgene was found behaving as monogenic dominant gene due to their hemizygous state in recipient genome, and thus segregated as dominant loci in a classic 3:1 Mendelian ratio (Cambell et al., 2000). Two major characteristics of transgenic populations are that the transgene may be present in many copies and molecular rearrangements can create an unstable transgenic locus, which leads to segregate independently and evolve continuously. Also, deletion, duplication, repeated sequence recombination, as well as gene interaction, nature of recipient genome, nature of transgene and interaction between them seems to contribute to non-Mendelian segregation of transgenes as causal factor (Zhimin et al., 2004). Mehta et al. (2013) and Chander Rao et al. (2013) also reported segregation of TSV-CP and PBNV-NC genes in some of T1 peanut progeny lines in 3:1 Mendelian fashion. Similarly, Gao et al. (2015) also reported that the majority of transgenic soybean lines tested for Soybean mosaic virus resistance through inverted repeat-SMV-HC-Pro genes showed Mendelian pattern of inheritance with the expected ratio of 3:1.

Normal expression of transgenes in transgenic lines at transcript level was confirmed by reverse transcriptase PCR (RT$P C R$ ) and quantitative (real-time) PCR (qPCR). RT-PCR analysis of TSV-CP and PBNV-NC transcripts gave an amplification of 717 bp and 654 bp in transgenic lines, respectively. However, no amplification was recorded in wild type plants. To check the 

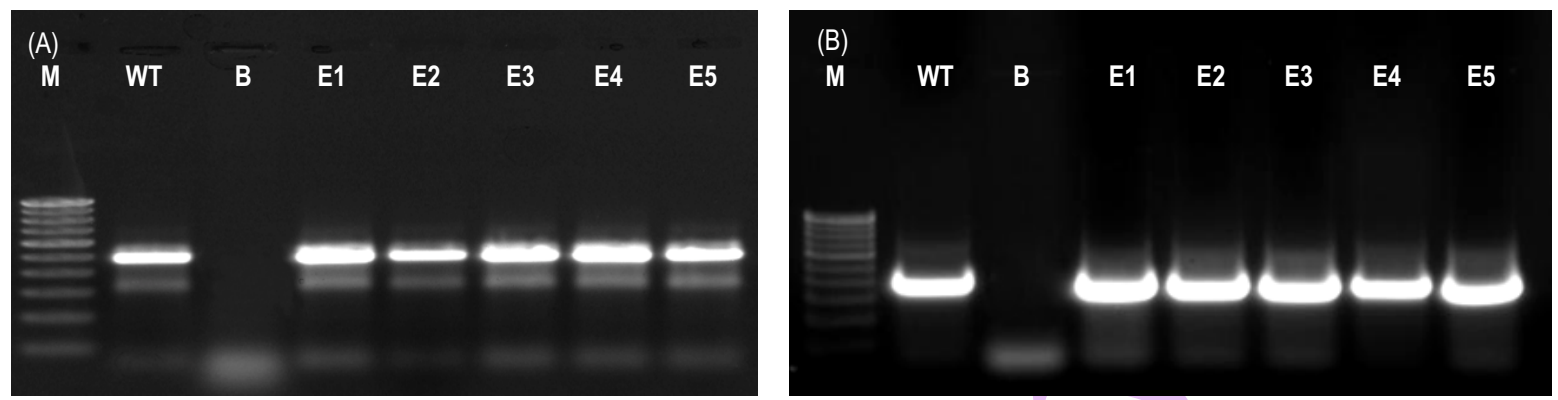

Fig. 2: RT-PCR base detection of challenge inoculum load of TSV and PBNV on transgenic (T5) and WT peanut plants to confirm the presence of challenge virus inoculums. RT-PCR analysis of (A) TSV-Putative viral replicase gene; the total mRNA from the TSV challenge inoculated transgenic and WT peanut plants were extracted and the first strand cDNA was prepared. Gene-specific primers were used to amplify 507 bp fragment of the TSVPutative viral replicase gene. Lanes, M: 100 bp ladder, WT: wild type peanut plant, B: Blank, E1-E5: transgenic events. (B) PBNV-Nonstructural movement protein gene; the total mRNA from the PBNV challenge inoculated transgenic and WT peanut plants were extracted and the first strand cDNA was prepared. Gene-specific primers were used to amplify $406 \mathrm{bp}$ fragment of the PBNV-Nonstructural movement protein gene. Lanes, M: $100 \mathrm{bp}$ ladder, WT: wild-type peanut plant, B: Blank, E1-E5: transgenic events

(A)

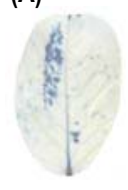

WT

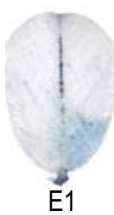

(B)
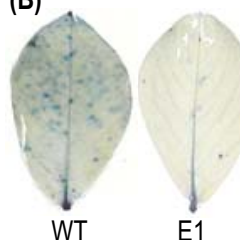

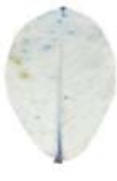

E2
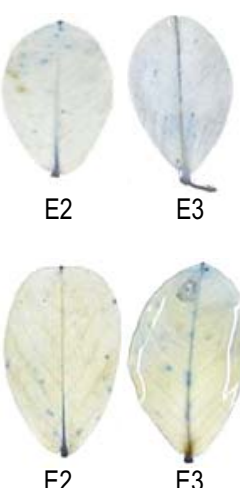

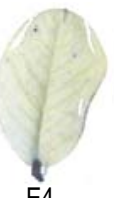

E4

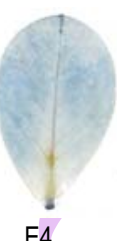

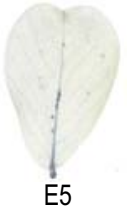

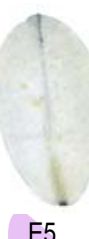

E5

Fig. 3: Histopathology of WT and transgenic (T5) leaves for micronecrosis symptom challenged inoculated with TSV and PBNV and stained with lacto-phenol-trypan blue (A) TSV infection and (B) PBNV infection

stringency of reaction conditions, 18S rRNAgene was amplified from the same cDNA, using gene specific primer pairs and under similar PCR conditions which resulted in 148 bp amplicon. RTPCR results showed that five transgenic events expressed TSVCP and PBNV-NC gene(s) at transcript level. Mehta et al. (2013) and Chander Rao et al. (2013) also reported similar kind of RTPCR analysis for TSV-CP and PBNV-NC transcripts in transgenic peanuts, respectively.

The TSV-CP and PBNV-NC gene expressions were analyzed at transcript level through $\mathrm{QPCR}$. The $\mathrm{C}_{T}$ values obtained were used for calculation of relative fold expression of transgene through $\Delta \Delta \mathrm{C}_{T}$ method (Table 3). The transgenic event E1 showed highly significant expression levels (1.40 times), compared to the calibrator (Table 3 ). Similar reports of multiple

folds increase in the transcript expression was recorded by Mehta et al. (2013), compared to the lowest expressing line for TSV-CP transcript in transgenic peanut plants. The TSV-CP transcripts showed similar trends of expression among different event plants. Similarly, Valkonen and Savenkov (2001) also reported steadystate level of CP gene mRNA were greatly increased in the plants infected with PVY. Also, the PBNV-NC transcripts showed more or less even trends of expression among different events. The transgenic event $E 1$ showed highly significant expression levels (1.85 folds), compared to the calibrator (Table3). Overall, qPCR results indicated that five events showed differential folds mRNA expressions in dual construct transgenic peanut plants.

Transgenic and wild type peanut plants were grown in glasshouse conditions for 2 weeks before virus inoculation and plants were mock-inoculated with TSV and PBNV and observed for virus symptoms. The TSV symptoms in transgenics were delayed and showed chlorotic spots on young leaves and necrotic lesions on young quadrifoliates leaflets. Transgenics showed declining TSV expressions, this might be due to high expression of TSV-CP protein which in turn retarded and delayed the TSV disease development. While wild type inoculated plants showed sudden wilting of leaflet and petiole, head drooping, upward killing of bud, and within a month plant died of necrosis.

The CP genes have been successful in averting the viral infection or reducing the diseases caused by homologous and narrowly related viruses (Gonsalves et al., 1993). Mehta et al. (2013) also reported resistance in different events to TSV in T2 and T3 progenies with no early symptoms of disease development. The studies by other workers have also reported delayed symptoms (Srivastava and Raj, 2008; Nakajima et al., 1993). Srivastava and Raj (2008) reported resistance in transgenic plants that remained symptomless throughout their life cycle, although virus accumulated at high level in their upper 
Table 3: Level of TSV-CPand PBNV-NC transcripts in five transgenic events as determined by qPCR

\begin{tabular}{|c|c|c|c|c|c|}
\hline Plant No. & $T S V-C P C_{T}$ & $18 \mathrm{SC}_{\mathrm{T}}$ & $\Delta \mathrm{C}_{\mathrm{T}}$ & $\Delta \Delta \mathrm{C}_{\mathrm{T}}$ & $\begin{array}{l}\text { Normalized quantity of } T S V-C P \text { transcript } \\
\text { relative to calibrator } 2^{-\Delta \Delta C_{T}}\end{array}$ \\
\hline E1 & 10.47 & 26.31 & -15.84 & -0.47 & 1.40 \\
\hline E2* & 10.62 & 25.99 & -15.37 & 0.00 & 1.00 \\
\hline E3 & 10.54 & 26.27 & -15.74 & -0.37 & 1.29 \\
\hline E4 & 10.59 & 26.35 & -15.76 & -0.39 & 1.31 \\
\hline E5 & 10.42 & 26.05 & -15.63 & -0.26 & 1.20 \\
\hline Plant No. & PBNV-NCC ${ }_{T}$ & $18 \mathrm{SC}_{\mathrm{T}}$ & $\Delta \mathrm{C}_{\mathrm{T}}$ & $\Delta \Delta \mathrm{C}_{\mathrm{T}}$ & $\begin{array}{l}\text { Normalized quantity of } P B N V-N C \text { transcript } \\
\text { relative to calibrator } 2^{-\triangle C_{T}}\end{array}$ \\
\hline E1 & 29.23 & 28.61 & 0.62 & -0.89 & 1.85 \\
\hline E3 & 29.34 & 28.66 & 0.68 & -0.83 & 1.78 \\
\hline E3 & 29.29 & 28.52 & 0.77 & -0.74 & 1.66 \\
\hline $\mathrm{E} 4^{*}$ & 29.64 & 28.13 & 1.51 & 0.00 & 1.00 \\
\hline E5 & 29.63 & 28.51 & 1.12 & -0.39 & 1.31 \\
\hline
\end{tabular}

Table 4 : Concentration of TSV and PBNV through DAC-ELISA after challenge inoculation with TSV and PBNV on transgenic peanut seedlings (T5) and wild type after 3 weeks of sowing

\begin{tabular}{llll}
\hline Details of samples & $\begin{array}{l}\text { DAC-ELISA reading for } \\
\text { TSV titer }\left(\mathbf{A}_{\text {405nm }}\right)(1 \mathrm{hr})\end{array}$ & Details of samples & $\begin{array}{l}\text { DAC-ELISA reading for } \\
\text { PBNV titer }\left(\mathbf{A}_{\text {405m }}\right)(\mathbf{1 h r})\end{array}$ \\
\hline Coating Buffer & 0.00 & Coating Buffer & 0.00 \\
Wild type $(\mathrm{WT})$ & 0.17 & Wild type $(\mathrm{WT})$ & 0.44 \\
Healthy peanut $(\mathrm{K}-6)$ & 0.00 & Healthy peanut $(\mathrm{K}-6)$ & 0.00 \\
Cowpea infected & 0.20 & Cowpea infected & 0.15 \\
E1 & 0.06 & E1 & 0.15 \\
E2 & 0.06 & E2 & 0.06 \\
E3 & E3 & 0.09 \\
E4 & 0.09 & E4 & 0.07 \\
E5 & 0.06 & E5 & 0.07 \\
\hline
\end{tabular}

leaves (but less than control). Higher CP level in inoculated transgenic plants have most likely affected the uncoating of the virus particle at later stages. Reimann-Philipp (1998) reported a reduced rate of virus growth in inoculated leaves and slower spread were frequently observed in transgenic CP-accumulated plants owing to slower replication rate or interference with local and systemic virus transport. Higher accumulation of TSV in inoculated leaves but no systemic spread may be due to interference either with entry into the phloem and vascular longdistance transport (Taliansky and Gracia-Arenel, 1995). Sharma and Anjaiah (2000) created transgenic peanuts carrying coat protein gene (IPCV cp) for resistance to Indian peanut clump virus (IPCV). The resistance shown by transgenic peanut plants to TSV is likely to be protein-mediated as CP was detected by ELISA in the leaves of transgenics. It may be due to the interactions of TSV$\mathrm{CP}$ in the transgenic plant and viruses in the challenge inoculums (Bendahmane et al., 2007).

Moreover, Asurmendi et al. (2007) postulated that the state of aggregation of CPs is correlated with the level of CP- mediated resistance (CPMR). As changed levels of resistance are indicated, there could be a connection of several mechanisms. A transgene can confer both protein and RNAmediated protection (Prins et al., 2008). However, Chapman et al. (2004) suggested that resistance may also be conferred by inhibiting cell to cell movement of viral particles since coat protein is often a necessary cofactor in that reaction.

After challenge inoculum of PBNV, the wild type peanut plant was visualized with symptoms of chlorotic lesions on terminal leaflets, necrosis of terminal bud (exposed with arrow) and axillary shoot proliferation with small and deformed leaflets. Infected plants remain stunted. Whereas, transgenic peanut plants with NC protein showed deferred (of 2-3 weeks) in symptom expression and attenuation with PBNV concluded that high expression of PBNV-NC protein retarded and delayed the disease development by PBNV. Interestingly, in transgenics plants no axillary shoot proliferation was observed. Introduction of viral NC gene by genetic transformation is a speedy and effective means to generate novel resistance against viral diseases in crop 
plants. Chander Rao et al. (2013), engineered popular Spanish groundnut CV. JL-24, using two methods of gene transfer with PBNV-NC gene, and T1 generation transgenic peanut plants revealed that 16 of the 35 tested transgenic plant lines (45.7\%) did not acquire virus under greenhouse condition.

RNA expression and production of nucleocapsid protein from sense $N C$ gene among the progenies of transgenic peanut plants witnessed a delay in symptom development by $10-15$ days after mechanical inoculation with donor isolate of TSWV and it attributes to hybridization of sense NC gene, RNA with the genomic RNA of incoming virus causing inhibition of viral RNA replication after introduction into plant cells (Yang et al., 2004). In another report, transgenic plants developed against the same virus using antisense NC gene had also been evaluated in field for expression and noted signiûcantly effective up to $76.0 \%$ symptomless plants for TSWV infection after 10 and $14 \mathrm{wk}(\mathrm{s})$ of sampling points (Magbanua et al., 2000). Similarly, Peart et al. (2002) investigated the role of tobacco NC orthologue in transgenic $N$. benthamiana showing resistance to a tobacco mosaic virus.

The DAC-ELISA conducted on the upper leaves of transgenic plants showed reduced virus accumulation as compared to wild type. All the transgenic lines tested showed resistance to TSV and PBNV infection in ELISA experiments. The results of DAC-ELISA indicated more virus titer values in wild type than transgenic peanut lines for TSV and PBNV (Table 4). Similar observations of DAC-ELISA were also recorded for more virus titer values in wild type than transgenic peanut plants for TSV (Mehta et al., 2013). In addition, transgenic peanut plants harbouring NC gene were also tested for expression through ELISAin the progenies (Yang et al., 1998).

After challenge inoculum of TSV and PBNV to transgenic and wild type peanut plants, RT-PCR analysis were carried out to determine the presence of virus inoculums load. The RT-PCR with primer pair of TSV-Putative viral replicase gene amplified a 507 bp fragment and PBNV-Nonstructural movement protein gene, a 406 bp fragment, respectively. RT-PCR results confirmed the presence of virus on both, transgenic events and wild type challenge inoculated plants (Fig. 2).

Quick and proficient detection of any pathogen is decisive for the progress and deployment of disease management strategies. In the study, two viral agents that cause peanut stem necrosis diseases and peanut bud necrosis disease were developed and tested. These were the most devastating peanut viral diseases whose diagnosis becomes very difficult when there is co-infection of TSV and PBNV, because both the viruses produce terminal bud necrosis. This RT-PCR based detection contributed to the development of diagnostic tools necessary for developing host plant resistance. The RT-PCR based detection of different viruses in peanut was also reported by Anitha et al.(2014) and Prasada Rao et al. (2003).

Staining of infected peanut leaves (A) TSV and (B) PBNV with trypan blue to wild type and transgenic were visualized as a dark blue and brown coloration, respectively, for cell death due to micro-necrosis. Wild type peanut leaves showed larger phenotypic symptoms of micro-necrosis spots at infection site than the transgenic peanut leaves (Fig. 3).Similar type of micronecrosis symptom development with trypan blue was reported by Permar et al. (2014) in Vigna unguiculata for Tospo viral infection.

In the present inv estigation, the evaluation of the transgenic peanutlines showed that the resistance could be obtained for both the viruses. The novelty of the work is that the marker free Agrobacterium-mediated transformation was used to generate transgenic plants for the first time for concurrent resistance to TSV and PBNV. Therefore, this strategy can be applied to commercially important crops that are affected by Ilarvirus and Tospoviruses. Information on molecular characterization of dual construct transgenic peanut plants has provided a better understanding of the viral diseases and contributed to the development of diagnostic tools necessary for developing host plant resistance. Further investigations would be taken up in future for determining the efficacy and performance of identified transgenic lines at field level under natural infection pressures.

\section{Acknowledgment}

The Department of Biotechnology, New Delhi, India is gratefully acknowledged for financial support.

\section{References}

Anitha, S., E.S. Monyo and P. Okori: Simultaneous detection of groundnutrosette assistor virus (GRAV), groundnut rosette virus (GRV) and satellite RNA (satRNA) in groundnuts using multiplex RT-PCR. Arch. Virol., 159, 3059-3062 (2014).

Asurmendi, S., R.H. Berga, T.J. Smitha, M. Bendahmane and R.N. Beachy:Aggregation of TMV-CP plays a role in CP functions and in coat-protein mediated resistance. Virology, 366, 98-106 (2007).

Baulcombe, D.C.: Mechanisms of pathogen-derived resistance to viruses in transgenic plants. Plant Cell, 8, 1833-1844 (1996).

Beachy, R.N.: Mechanisms and applications of pathogen-derived resistance in transgenic plants. Curr. Opin. Biotech., 8, 215-20 (1997).

Bendahmane, M., I. Chen, S. Asurmendi, A.A. Bazzini, J. Szecsi and R.N. Beachy: Coat protein-mediated resistance to TMV infection of Nicotiana tabacum involves multiple modes of interference by coat protein. Virology, 366, 107-16 (2007).

Cambell, B.T., P.S. Baenziger, A.Mitra, S. Sato and T. Clemente: Inheritance of multiple transgenes in wheat. Crop Sci., 40, 1133$1141(2000)$.

Chander Rao, S., P. Bhatnagar-Mathur, P.L. Kumar, A.S. Reddy and K.K. Sharma: Pathogen-derived resistance using a viral nucleocapsid gene confers only partial non-durable protection in peanut against peanut bud necrosis virus. Arch. Virol., 158,133-143 (2013). 
Chapman, E.J., A.I. Prokhnevsky, K. Gopinath, V.V. Dolja and J.C. Carrington: Viral RNA silencing suppressors inhibit the microRNA pathway at an intermediate step. Genes Dev., 18, 1179-1186 (2004).

Cuc, L.M., E.S. Mace, J.H. Crouch, V.D. Quang, T.D. Long and R.K. Varshney: Isolation and characterization of novel microsatellite markers and their application for diversity assessment in cultivated groundnut (Arachis hypogaea L.). BMC Plant Biol., 8, 55-65 (2008).

FAOSTAT: Food and Agriculture Organization of the United Nations. FAOSTAT Database. Rome, Italy: FAO. Retrieved 24th September, 2015 from http://www.fao.org/faostat/en/\#home (2014).

Gao, L., X. Ding, K. Li, W. Liao, Y. Zhong, R. Ren, Z. Liu, K. Adhimoolam and $\mathrm{H}$. Zhi: Characterization of Soybean mosaic virus resistance derived from invertedrepeat-SMV-HC-Pro genes in multiple soybean cultivars. Theor. Appl. Genet., 128, 1489-1505 (2015).

Hefferon, K.L., H. Khalilian and M.G. Abou Haidar: Expression of the PVY (O) coat protein $(C P)$ under the control of the PVX CP gene leader sequence: protection under greenhouse and field conditions against PVY $(\mathrm{O})$ and PVY $(\mathrm{N})$ infection in three potato cultivars. Theor. Appl. Genet., 94,287-292 (1997).

Hobbs, H.A., D.V.R. Reddy, R. Rajeswari and A.S. Reddy: Use of direct antigen coating and protein A coating ELISA procedures for detection of three peanut viruses. Plant Dis., 71, 747-749 (1987).

Jain, R.K., K. Vemana and S. Bag: Tobacco streak virus- An emerging virus in vegetable crops. In: Characterization, diagnosis and management of plant viruses. Vegetable and pulse crops (Eds.: G.P. Rao., P.L. Kumar and H. Pena). Stadium Press LLC, U.S.A., Houston, Texas-77072, U.S.A., 3, pp. 203-212 (2008).

Kandakoor, S.B., H.K. Khan, A.K. Chakravarthy, C.T. Kumar and P. Venkataravana. Biochemical constituents influencing thrips resistance in groundnut germplasm. J. Environ. Biol., 35, 675-81 (2014).

Li, Z.J., R.L. Jarret and J.W. Demski: Engineered resistance to tomato spotted wilt virus in transgenic peanut expressing the viral nucleocapsid gene. Transgenic Res., 6, 297-305 (1997).

Livak, K.J. and T.D. Schmittgen: Analysis of relative gene expression data using real-time quantitative PCR and the 2DDCT method. Methods, 25, 402-408 (2001).

Magbanua, Z.V., H.D. Wilde, J.K. Roberts, K. Chowdhury, J. Abad, J.W. Moyer, H.Y. Wetzstein and W.A. Parrott: Field resistance to tomato spotted wilt virus in transgenic peanut (Arachis hypogaea L.) expressing an antisense nucleocapsid gene sequence. Mol. Breed., 6, 227-236 (2000).

Mehta, R., R. Yadav, T. Radhakrishnan, A. Kumar, J.R. Dobaria, P.P. Thirumalaisamy, R.K. Jain and P. Chigurupati: Coat proteinmediated transgenic resistance of peanut (Arachis hypogaea L.) to peanut stem necrosis disease through Agrobacterium-mediated genetic transformation. Indian J. Virol., 24, 205-213 (2013).

Mishra, G.P., T. Radhakrishnan, A. Kumar, P.P. Thirumalaisamy, N. Kumar, T.C. Bosamia, B. Nawade and J.R. Dobaria: Advancements in molecular marker development and their applications in the management of biotic stresses in peanuts. Crop Prot., 77, 74-86 (2015).

Nakajima, M., T. Hayakawa, I. Nakamura and M. Suzuki: Protection against cucumber mosaic virus (CMV) strains $O$ and $Y$ and chrysanthemum mild mottle virus in transgenic tobacco plants expressing CMV-O coat protein. J. Gen. Virol., 74, 319-322 (1993).

Pearson, K.: On the criterion that a given system of deviations from the probable in the case of a correlated system of variables is such that it can be reasonably supposed to have arisen from random sampling. Philo. Mag., 50, 157-175(1900).

Peart, J.R., G. Cook, B.J. Feys, J.E. Parker and D.C. Baulcombe: An EDS1 orthologue is required for $\mathrm{N}$-mediated resistance against tobacco mosaic virus. Plant J., 29, 569-579 (2002).

Permar, V., A. Singh, V. Pandey, A.A. Alatar, M. Faisal, R.K. Jain and P. Shelly: Tospo- viral infection instigates necrosis and premature senescence by micro RNA controlled programmed cell death in Vigna unguiculata. Physiol. Mol. Plant P., 88, 77-84 (2014).

Pradeep K., V.K. Satya, M. Selvapriya, A. Vijayasammundeeswari, D. Ladhalakshmi, V. Paranidharan, R. Rabindran, R. Samiyappan, P. Balasubramanian and R. Velazhahan: Engineering resistance against tobacco streak virus (TSV) in sunflower and tobacco using RNAinterference. Biologia Plantarum, 56, 735-741 (2012).

Prasad Rao, R.D.V.J., D.V.R. Reddy, S.N. Nigam, A.S. Reddy, F. Waliyar, T. Yellamanda Reddy, K. Subramaniam, M. John Sudheer, K.S.S. Naik, A. Bandyopadhyay, S. Desai, M.P. Ghewande, M.S. Basu and Somasekhar: Peanut stem necrosis: A new disease of groundnut in India. Bulletin No. 67, p.12 (2003).

Prins, M., M. Laimer, E. Noris, J. Schubert, M. Wassenegger and M. Tepfer: Strategies for antiviral resistance in transgenic plants. Mol. Plant. Pathol., 9, 73-83 (2008).

Reddy, A.S., R.D.V.J. Prasad Rao, K. Thirimala Devi, S.V. Reddy, M.A. Maya, I. Roberts, T. Satyanarayana, K. Subramaniam and D.V.R. Reddy: Occurrence of tobacco streak virus on peanut (Arachis hypogaea) in India. Plant Dis., 86, 173-178 (2002).

Reddy, D.V.R., A.A.M. Buiel, T. Satyanarayana, S.L. Dwivedi, A.S. Reddy, A.S. Ratna, K. Vijaya Lakshmi, G.V. Ranga Rao, R.A. Naidu and J.A. Wightman: Peanut bud necrosis disease: An overview. In: Recent studies on peanut bud necrosis disease (Eds.: A.A.M. Buiel, J.E. Parlevliet and J.M. Lenne). Proceedings of a meeting at ICRISAT Asia Center, Patancheru, pp. 3-7 (1995).

Reimann-Phillipp, U.: Mechanism of resistance: expression of coat protein. In: Methods in molecular biology, plant virology protocols: from virus isolation to transgenic resistance (Eds.: G.D. Foster and S.C. Taylor). Humana Press: New Jersey, 81, pp. 521-532 (1998).

Savenkov, E.I. and J.P.T. Valkonen: Coat protein gene-mediated resistance to potato virus $A$ in transgenic plants is suppressed following infection with another Potyvirus. J. Gen. Virol., 82, 22752278 (2001).

Sharma, K.K. and V. Anjaiah: An efficient method for the production of transgenic plants of peanut (Arachis hypogaea L.) through Agrobacterium tumefaciens-mediated genetic transformation. Plant Sci., 159,7-19 (2000).

Takemoto, D., D.A. Jones and A.R. Hardham: GFP-tagging of cell components reveals the dynamics of sub-cellular re-organization in response to infection of Arabidopsis by oomycete pathogens. Plant J., 33, 775-792 (2003).

Singh, A.K., A. Pedapati and Manibhushan: Assessment of exchange of crop in view of change climate and international treaties. J. Environ. Biol., 36, 309-317 (2015a).

Singh, D., T. Radhakrishnan, V. Kumar, N.B. Bagwan, M.S. Basu, J.R. Dobaria, G.P. Mishra and S.V. Chanda: Morphological and toxigenic variability in the Aspergillus flavus isolates from peanut (Arachis hypogaea L.) production system in Gujarat (India). J. Environ. Biol., 36,441-449(2015b).

Srivastava, A. and S.K. Raj: Coat protein mediated resistance against as Indian isolates of the cucumber mosaic virus subgroup IB in 
Nicotiana benthamiana. J. Bioscience, 33, 249-257 (2008).

Taliansky, M.E. and F. Garcia-Arenal: Role of cucumovirus capsid protein in long-distance movement within the infected plant. J. Virol., 69, 916-922 (1995).

Yang, H., C. Singsit, A. Wang, D. Gonsalves and P. Ozais-Akins: Transgenic peanut plants containing a nucleocapsid protein gene of tomato spotted wilt virus show divergent levels of gene expression. Plant Cell Rep., 17, 693-699 (1998).

Yang, H., P. Ozias-Akins, A.K. Culbreath, D.W. Gorbet, J.R. Weeks and H.R. Pappu: Field evaluation of tomato spotted wilt virus resistance in transgenic peanut (Arachis hypogaea). Plant. Dis., 88, 259-264 (2004).

Zhimin, Y., P. Wojciech and M. Stefan: Transgene inheritance in plants. J. Appl. Genetics, 45, 127-144 (2004). 